\title{
On the geological and economic assessment of the Lower Amur region (Russia)
}

\author{
Viktor Kryukov ${ }^{1}$ and Irina Kradenykh ${ }^{1}$ \\ ${ }^{1}$ Mining Institute FEB RAS, 51 Turgenev st., Khabarovsk, 680000, Russia
}

\begin{abstract}
The development of regional economy is based on medium and long-term strategies (programs) for economic industrialization. These documents are of a sectoral or int egrated nature. Republic of S akha (Yakutia) and Kamchatka Territory have a scientifically substantiated strategy for the development of the mining ind ustry. Des pite its abs ence in $\mathrm{K}$ habarovsk Territory, subsoil use in recent years has shown a steady growth in mining. The main volume of income comes from gold mining mainly in the northern and central parts of the region. Over the past 10 years, the most economically advantageous and geographically accessible minerals have been identified in the region. These include: coal, gold, platinum, tin, construction materials, groundwater. In the future, it is necessary to plan the development of copper-porphyry, alunite and poly metallic fields. The issues of increasing the resource base of liquid and strategic metals, formation of infrastructure, complexity of the use of mineral wealth and rational use of mineral resources remain prob lematic. A positiv e solution to problems is possible when developing and implementing an industry strategy. The basis for its formation is the geolog ical and economic assessment of particular territories of the region.
\end{abstract}

Keywords: Khabarovsk Territor y, industr ialization, go ld, $\mathrm{n}$ on-ferrous metals, fields, resource assessment, economic potential.

\section{Introduction}

The purpose of the study is to form a ge ological and economic model for the development of a certain area of Khabarovsk Territory, which has a sufficiently high resource potential.

The geological and economic assessment of certain territories, called: a te rritory of advanced development (ADT), the mineral resource sector (MRC), the mineral resource center (MRCr), is carried out on the basis of established reserves and officially approved resources. At the sam e time, the cate gory of re sources includes acc umulations of minerals identified by practical geologists, the verification of the quantity of which is limited to the stage of prospecting.

A large number of such objects were found even before the so-called market transformations. Their further study was discontinued either due to low and moderate metal grades, or due to their classification as "non-promising" ore formations. Currently, every five years, the number of resources is re-approved by the leading research institute. As a rule, there are no significant changes in the amount of resources.

This approach to assessing the potential of a territory is not always ju stified. Undoubtedly, ex perts take into account modern ideas about the prospects of some or other forma- 
tional type of ore content, diagnostics of a certain area of the Earth's crust fro $m$ the standpoint of plate tectonics, etc. However, the noted innovations often do not give any significant effect. The reas on is that many primary sources of geological information that allow identifying the genetic type of an object, the relations hip of ore accumulations with metasomatites, structural tectonic factors of ore localization and other features remain outside the field of view of researchers.

\section{Situation analysis, problem statement}

New approaches to assessi ng the potential and, accordingly, to the ec onomic forecast are considered taking as a case study one of the areas in Khabarovsk Territory. Within the territory, on an ar ea of about 787.6 thousand square $\mathrm{km}$, there are 13 ore-bearing areas, namely the f ollowing ( from no rth, so uthwards): Y udomo-Maisky, Okhotsk, Uc huro-Maisky, Dzhugdzhursky, V erkhneuchuro-Nemuisky, Ud skoy, Udsko-Toromsky, K erbinsky, Melginsky, Bureinsky, Amgunsky, Lower Amur and Khorsko-Anyuisky. The most studied of them in terms of gold content is Lower Amur [3].

The Lower Amur area stretches in the submeridional direction for $570 \mathrm{~km}$ with a width of about $330 \mathrm{~km}$. There are four gold fields in op eration - A lbazino, Mno govershinnoye, Belaya Gora and Polyanka. As a result of geological exploration in recent years, the following objects have been assessed: Blagodatnenskoe (15.9 t), Delkenskoe (12 t), Dyappe (62 t), Polyanka (12.4 t), Chulbatkan (31.5 t), Kutynskoe (24.1 t); the gold reserves at the Mnogovershinnoye field were increased to 58 t. Prospects are associated with 5 more fields.

In co nnection with the di scovery of the Malmyzh field, unique in terms of rese rves, porphyry c opper with gold (more than 5.2 million tons of copper and about 278 tons of gold), the value of 13 o ccurrences of similar typ e is i ncreasing. The largest secondar y quartzite obj ects I skinskoe, Krugly Kamen, Sh elekhovskoe can provide raw sto ck for the aluminum in dustry. The C hayatyn po lymetallic field was prep ared for d evelopment. The Seredochnoye zeolite field is lo cated near the Niko laevsk-on-Amur - Mnogovershinnoye highway. The tungsten content of the a rea, as well as the oil and gas c ontent of the KiziKadinsky depression, are assessed positively.

The scientific forecast for assessing the potential of the Lower Amur region methodically fits in two directio ns. The first is based on actual reserves and projected annual productivity of $\mathrm{m}$ ining and processing $\mathrm{plants}$ (MPPs). The sec ond (forecast) is based on the assessment of resou rces of the main minerals of th e co nsidered territory. Mean time, the choice of st andards f or co nstructing ge ological and ec onomic models, the sel ection of promising objects from a si gnificant number of small fields and ore occurrences, resource assessment and other issues are largely original. An integration of results of an analysis of the authors' research in the indicated areas provides a fairly high degree of forecast reliability.

Geological and economic models of a territory are composed of the following factors:

- real reserves of minerals;

- integration of data on reserves of particular fields into a single territorial system;

- geological and economic model of the territory of the first type;

- geological and structural models of reference objects;

- identification of promising objects by the main types of minerals;

- c omparison of p romising ore occ urrences wi th re ference fi elds for which s pecific productivity has been calculated;

- forecast of resources of the selected types of fields within the area;

- integration of data on the resources of the main types of minerals into a sing le territorial system;

- geological and economic model of the territory of the second type. 


\section{Results and Discussion}

In the short-to-medium term, by 2025, it is planned to develop 5 gold ore objects Delken, Dyappe, Kutynskoye, Chulbatkan, as w ell as th e porphyry co pper Malmyzh deposit. The annual production of metals in concentrates will amount to 24.5 tons for gold and 125 thousand tons for copper. Based on the amount of reserves, market conditions, current state of the raw material sources and prices predicted for 2025, the expected amounts of production proceeds and taxes on mineral extraction were found, taking into account its $r$ epayment to the regional budget (Table 1).

Table 1. Calculation of economic indicators in the production of minerals

\begin{tabular}{|c|c|c|c|c|c|c|}
\hline $\begin{array}{c}\text { Type of } \\
\text { minerals }\end{array}$ & $\begin{array}{c}\text { Annual } \\
\text { produc- } \\
\text { tion, } \mathrm{t}\end{array}$ & $\begin{array}{c}\text { Throughout } \\
\text { recovery } \\
\text { factor }\end{array}$ & $\begin{array}{c}\text { Estimated } \\
\text { price for } \\
2025, \\
\text { thousand } \\
\text { rubles } / \mathrm{t}\end{array}$ & $\begin{array}{c}\text { Amount } \\
\text { of pro- } \\
\text { ceeds, } \\
\text { million } \\
\text { rubles }\end{array}$ & $\begin{array}{c}\text { Federal budget, } \\
\text { mln rubles }\end{array}$ & $\begin{array}{c}\text { MET to the } \\
\text { regional } \\
\text { budget, mln } \\
\text { rubles }\end{array}$ \\
\hline Gold 24. & 5 & 0.9 & $4,527.33$ & 99.8 & 5.9 & 5.9 \\
\hline Copper & 125,000 & 0.77 & 680.51 & $65,499.3$ & $5,239.9$ & $3,144.0$ \\
\hline Total & - & - & - & $65,599.1$ & $5,245.9$ & $3,150.0$ \\
\hline
\end{tabular}

Taking in to account the expected price for minerals for 2025, the annual revenue may amount to more than 99 million rubles for gold, and about 65 billion rubles for copper. According to the Budget Code, the mineral extraction tax (MET) is calculated at $6 \%$ for gold and $8 \%$ for non-ferrous metals. The entire amount of tax of $100 \%$ goes to the Federal budget of the Russian Fed eration, then it is red istributed among the con stituent en tities of the Federation. So the MET calculated from the volume of $\mathrm{p}$ roceeds for gold is repaid to the regional budget in the am ount of $100 \%$, from no n-ferrous metals the repayment is $60 \%$. The total MET amount can provide revenues to the regional budget over 3 billion rubles worth $[1,2,5]$.

The volumes of metal recovery are given in accordance with the internal corporate plans for the de velopment. The potential of the area is determined by the presence of real re serves: gold (569.4 tons), copper (5.2 million tons), aluminum (4.54 million tons), lead (71 thousand tons), zinc (135 thousand tons), zeolites ( 81.33 million tons). Based on the above value of reserves and the forecast prices for minerals, the potential value of the said area for the period up to 2030 was found - option 1 (Table 2.)

As a result, an in tegrated assessment of the potential value of the area under consideration was ob tained. The calculations used the data related to prices for mineral resou rces, taking into account the long-term socio-economic development of the Russian Federation. In monetary terms, the total potential value of this area for the study period may amount to more than USD 4,582 billion.

Table 2. Assessment of the potential value of the area in the long term

\begin{tabular}{|c|c|c|c|c|}
\hline Type of minerals & $\begin{array}{c}\text { Volume of ex- } \\
\text { pected reserves }\end{array}$ & $\begin{array}{c}\text { Throughout recov- } \\
\text { ery factor }\end{array}$ & $\begin{array}{c}\text { Estimated price, } \\
\text { thousand rubles / t }\end{array}$ & $\begin{array}{c}\text { Potential value of } \\
\text { object, bln rubles }\end{array}$ \\
\hline Gold 569. & 4 & 0.9 & $4,895.1$ & 2.5 \\
\hline Copper 5, & 200,000 & 0.77 & 794.6 & $3,181.7$ \\
\hline Aluminum & $4,540,000$ & 0.65 & 202.9 & 598.9 \\
\hline Lead 71, & 000 & 0.72 & 148.4 & 17.1 \\
\hline Zinc & 135,000 & 0.7 & 180.7 & 775.0 \\
\hline Zeolites & $81,330,0000.85$ & & 11.2 & $4,582.8$ \\
\hline Total & - & - & - & \\
\hline
\end{tabular}

In the medium term, by 2025, gold fields Agnie-Afanasyevskoye, B lagodatnenskoye, Dylmenskoye, Le vodzhegdagskoye, P okrovsko-Troitskoye, c opper-porphyry fields Avlanbir, Zolotaya Gora, Zimovye, Kabachinskoye, Nochnoye, Poniyskoye, Tyrskoye, and 
also Shelekhovskoye, Iskinskoye and Gryada Kamenistaya may be additionally involved in operation [4]. On the territory of the Lower Amur region, the production facilities of about 20 MPPs will be launched, providing for an output of about 40 ton s of gold, 325 thousand tons of copper and 120 thousand tons of aluminum per year. Based on these indicators, the values of the expected production proceeds and MET were also calculated (Table 3).

Table 3. Calculation of economic indicators in the production of minerals

\begin{tabular}{|c|c|c|c|c|c|c|}
\hline $\begin{array}{c}\text { Type of } \\
\text { minerals }\end{array}$ & $\begin{array}{c}\text { Annual } \\
\text { produc- } \\
\text { tion, } \mathrm{t}\end{array}$ & $\begin{array}{c}\text { Throughout } \\
\text { recovery } \\
\text { factor }\end{array}$ & $\begin{array}{c}\text { Estimated price } \\
\text { for 2025, } \\
\text { thousand rubles } \\
/ \mathrm{t}\end{array}$ & $\begin{array}{c}\text { Amount of } \\
\text { proceeds, } \\
\text { million ru- } \\
\text { bles }\end{array}$ & $\begin{array}{c}\text { MET to the } \\
\text { Federal } \\
\text { budget, mln } \\
\text { rubles }\end{array}$ & $\begin{array}{c}\text { MET to the } \\
\text { regional budg- } \\
\text { et, mln rubles }\end{array}$ \\
\hline Gold 40 & & 0.9 & $4,527.33$ & 163.0 & 9.8 & 9.8 \\
\hline Copper & 325,000 & 0.77 & 680.51 & $170,298.1$ & $13,623.9$ & $8,174.3$ \\
\hline Aluminum & 120,000 & 0.65 & 173.82 & $13,558.3$ & $1,084.7$ & 650.8 \\
\hline Total - & & - & - & $184,019.4$ & $14,718.3$ & $8,834.9$ \\
\hline
\end{tabular}

In monetary terms, the total proceeds from the sale of commercial products will amount to about 184 billion rubles, and tax receipts to the regional budget will amount to more than 8 billion rubles.

The resource potential of this area in the future for 2030 (Table 4) is shown as option 2 , determined by the presence of gold (1,200 tons), copper (15 million tons), aluminum (10 million tons), lead (150 thousand tons), zinc (400 thousand tons), tungsten ( 150 thousand tons), zeolites (81.3 million tons).

Table 4. Assessment of the potential value of the area in the long term

\begin{tabular}{|c|c|c|c|c|}
\hline Type of minerals & $\begin{array}{c}\text { Volume of expected } \\
\text { reserves }\end{array}$ & $\begin{array}{c}\text { Throughout re- } \\
\text { covery factor }\end{array}$ & $\begin{array}{c}\text { Estimated price, } \\
\text { thousand rubles } \\
/ \mathrm{t}\end{array}$ & $\begin{array}{c}\text { Potential value of } \\
\text { object, bln rubles }\end{array}$ \\
\hline Gold 1, & 200 & 0.9 & $4,895.1$ & 5.3 \\
\hline Copper 15, & 000,000 & 0.77 & 794.6 & $9,177.9$ \\
\hline Aluminum 10, & 000,000 & 0.65 & 202.9 & $1,319.3$ \\
\hline Lead 150, & 000 & 0.72 & 148.4 & 16.0 \\
\hline Zinc 400, & 000 & 0.7 & 180.7 & 30.6 \\
\hline Tungsten 150, & 000 & 0.55 & $3,970.3$ & 774.7 \\
\hline Zeolites 81,300,000 & 00 & 0.85 & 11.2 & $11,671.3$ \\
\hline Total - & & - & - & 1 \\
\hline
\end{tabular}

To compare the potential value of the two areas, a diagram is built enabling to identify their conditional rating (Fig. 1). According to calculations, the value of the area as a percentage in the first option is almost three times less than in the second option (Fig. 1). This is due to the fact that in the assessment of the resource potential of the territory covers all the main types of minerals, and for gold and aluminum, an increase in reserves is predicted due to the exploration of new (or well forgotten old) small fields and ore occurrences. 


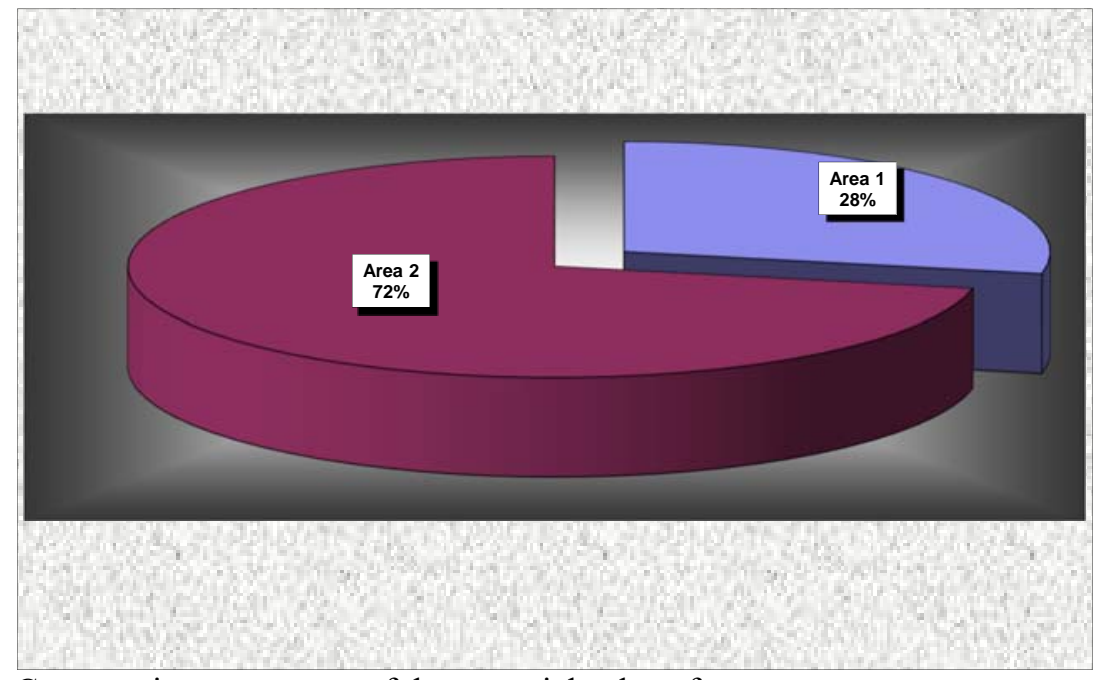

Fig. 1. Comparative assessment of the potential value of areas

The assessment of the potential value shows the priority of d evelopment of the objects under consideration in the current state of the regional raw material source. It ca $\mathrm{n}$ be expected that bringing these reserves to development will be economically viable in the medium and long term.

\section{Conclusion}

Thus, a new approach is proposed in the development of geological and economic models of fairly larg e territories, in cluding sev eral ore re gions. So, withi $\mathrm{n}$ the Lower Amur area over the past 12-15 years, about ten gold fields considered small (Albazino, Belaya Gora, Dyappe, etc.) have been transferred to the category of m edium and 1 arge. Reserves have been prepared at one of them and the prospects for copper-porphyry occurrences have been identified. The possibility of increasing the raw material sources by studying the tungsten, polymetallic and sec ondary quartzite manifestations of the L ower Amur re gion was estimated. The aforesaid allows one to give a forecast assessment of the area in a new way and form its geological and economic model.

For the area, two variants of the geological and economic model were formed. The first is based on real reserves of gold and copper. It includes the current production of metals, the co rresponding revenues to the budgets of the Fed eration and the region, as $\mathrm{w}$ ell as a forecast due to the i nvolvement of practically explored gold fields and the possible development of reserves of lead, zinc and zeolites. The second option is based not only on the reserves of minerals, but also on the resources identified by promising objects by comparing them with reference fields with known reserves. Increase in reserves of gold and copper is forecasted. The list of types of minerals is expanding due to tungsten. In general, according to the second option, the area seems to be more promising for its systematic development over the next decades.

\section{References}

1. I.A. Kradenykh, A.V. Barchukov, Mining information and analytical bulletin (scientific and technical journal), S4, 363-375 (2013)

2. I.A. Kradenykh, A.V. Barchukov, Notes of the Mining Institute, 211, 43-52 (2015)

3. I. Yu. Rasskazov, V. G. Kryukov, Mining journal, 10, 5-12 (2018) 
4. V. Kryukov, E3S Web of Conferences: VII International Scientific Conference "Problems of Complex Development of Georesour ces", Khabarovsk, Russia, September 25-27, 56 (2018) - URL: https://www.e3s-conferences.org

5. V.S. Litvintsev, V.S. Alekseev, I.A. Kradenykh, Problems of Complex Development of Georesources electronic resource. "E3S Web of Conferences" 01005 (2018) 